2. Jensen F.V. (1996). An Introduction to Bayesian Networks, UCW Press Limited, London, $178 \mathrm{p}$.

3. Laskey K. B. (1996). Model Uncertainty: Theory and Practical Implications. IEEE Transactions on Systems, Man and Cybernetics - Part A: Systems and Humans, Vol. 26, No 3, pp. $340-348$.

4. Laskey K. B. And Lehner P. E. (1994). Metareasoning and the Problem of Small Worlds. IEEE Transaction on Systems, Man and Cybernetics, Vol. 24, No 11, pp. $1643-1652$.

\title{
MAPPING POTENTIAL AREAS OF GROUND SUBSIDENCE IN ESTONIAN UNDERGROUND OIL SHALE MUNING DISTRICT
}

\author{
INGO VALGMA \\ The Mining Institute of Tallinn Technical University, Kopli 82, Tallinn, 10412, Estonia, \\ Internet address htpp://www.ttu.ee/maeinst/ \\ Phone: +372 62038 50, Fax: +37262036 96, E-mail: ingoval@cc.ttu.ee
}

\begin{abstract}
Northeast part of Estonia has been subject to oil shale mining since 1916. Oil shale as main source for power industry in Estonia is mined in amount of 12 million tonnes per year. The underground production rate is about 6 million tomes of the mineral annually. Currently three open casts and six underground mines are operating. In past 6 underground oil shale mines have been closed. Totally 979 million tonnes of rock, including oil shale has been mined underground. Today, about $305 \mathrm{~km}^{2}$ area has 512 million $\mathrm{m}^{3}$ abandoned mine workings in the depth of 10 to $70 \mathrm{~m}$ below the surface. The problem is influence of underground mining and mine workings on ground subsistence and ground- and surface water regime.

Mapping of potential areas of ground subsidence started in the Mining Institute of Tallinn Technical University with MapInfo Professional. GIS is used because of need for locating the tunnels in current geographic situation. As database for digitizing and scanning, available mine maps and drawings are used. Fieldwork is included for recognizing collapse areas in nature. For further analyses, MaphInfo features and additionally, Vertical Mapper are used.

In future groundwater problems will be included in the study. The study is partially supported by Tallinn Technical University by purchasing software MaplInfo. Estonian Mapping Centre has supported the study with making available to use base map of Estonia for reference.
\end{abstract}

\section{Estonian oil shale overview}

Baltic oil shale area (See Figure 1) covers about fifty thousand square kilometers, its oil shale, from Middle Ordovician age is named kukersite oil shale. The Baltic area includes the Estonia and Leningrad deposits and Tapa occurrences, of which the first two are commercially exploited. Estonia deposit is one of the largest 
commercially exploited oil shale deposits in the world with its total resources exceeding five billion tons of oil shale.

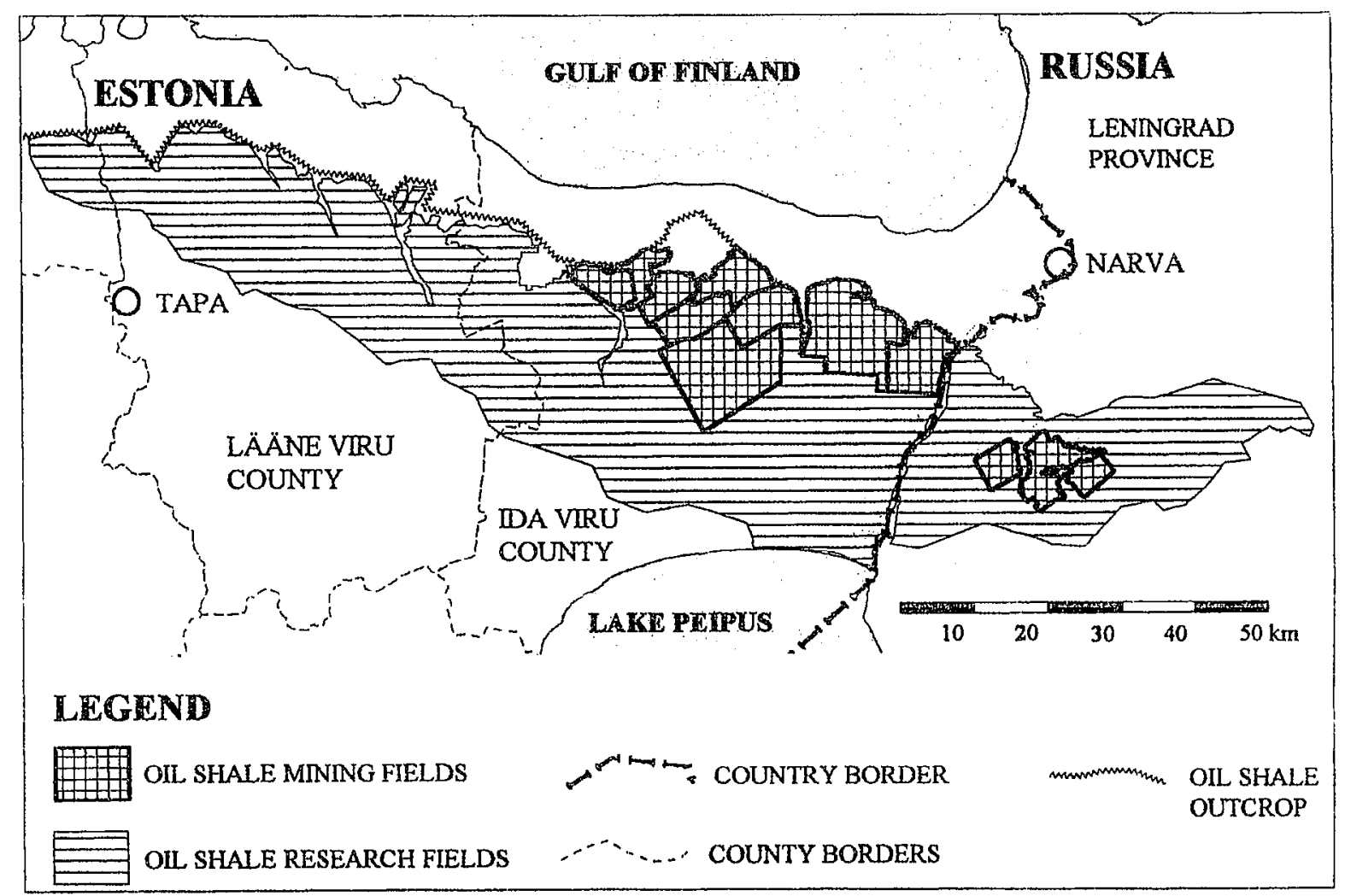

Figure 1. Map of the Baltic oil shale area

Oil shale production rate could be seen in figure 2 . The prognoses show inescapable decrease in the capacities. In this connection, collecting old mines data has special value today.

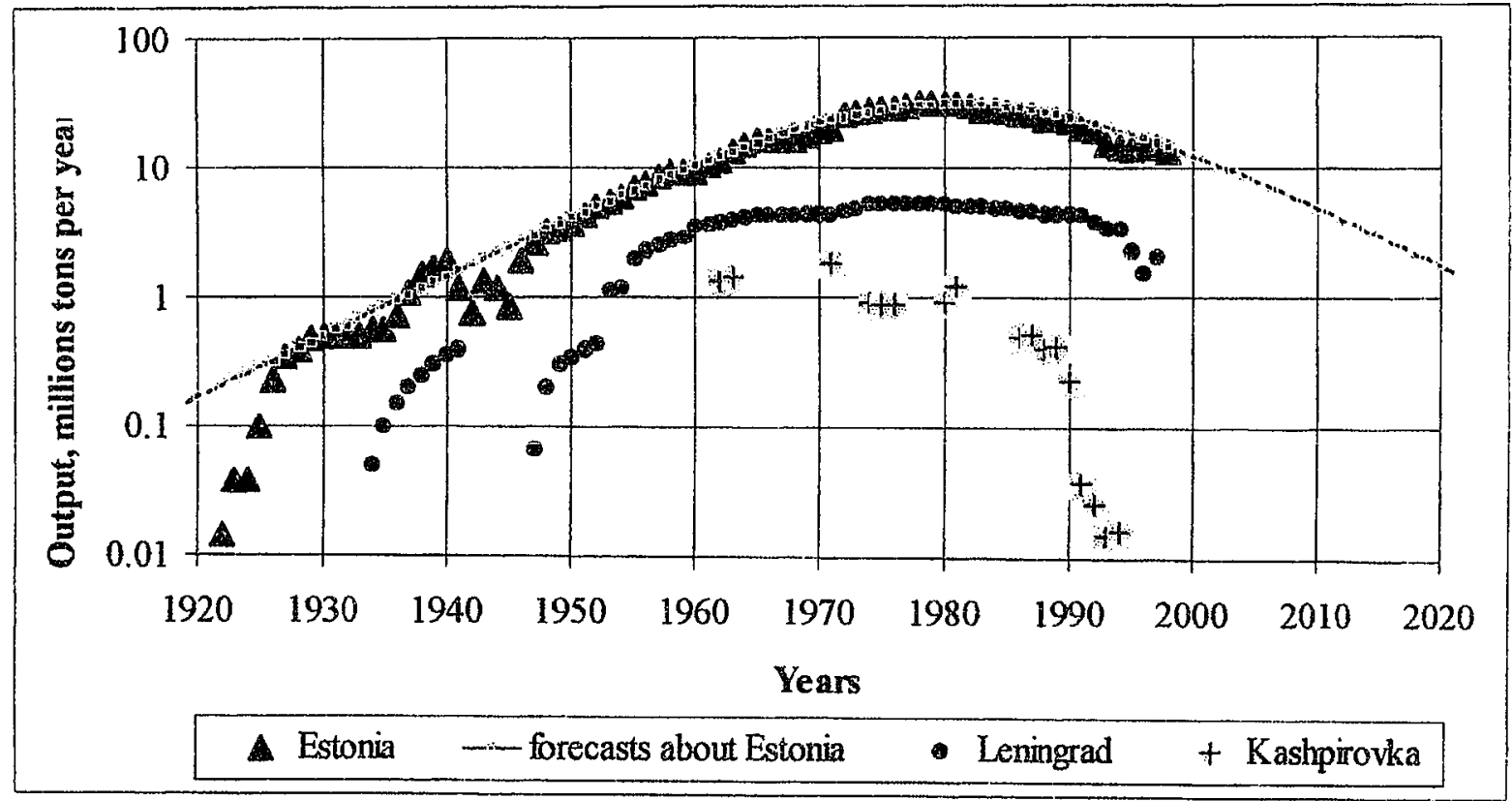

Figure 2. Oil shale production in Estonian and Russian deposits 


\section{Mapping Estonian oil shale deposit}

Creating digital maps of oil shale resources started in the Mining Institute at the end of 1997. Using Maplinfo Professional for mapping Estonian oil shale deposit is first trial in Estonia for mapping oil shale mining situation with help of modern Geographical Information Systems. The Mining Institute of Tallinn Technical University has started to create geographically referenced database of Estonian prime mineral resource.

The mapping stanted with locating oil-shale mining fields in local coordinate system and followed with digitizing underground paper maps. Data from geological investigations is available for creating grid files for overburden thickness, mineral bedding and surface topology. Coordinates for mining fields are available from Cadastre of Mineral Resources. For analyzing underground mining influences, exact current undergound space situation and previous situation is compared with surface topology in mined out areas. In the future groundwater problems will be included to the study. The study is supported by Tallinn Technical University by purchasing mapping software - MapInfo Professional. Estonian Map Centre has supported the study with making available to use base map of Estonia for reference.

Mapping mineral resources and mining situation needs both knowledge in geology and technology. As database, both raster and digital maps and layouts are used. Origin of maps is often multifarious; most of them come from mining industry through personal contacts of our employees. Surface elevation data has been taken through transferring data from Estonian base map (scale 1:50000). Vertical Mapper allows to visualize oil shale fields in three dimensional layout.

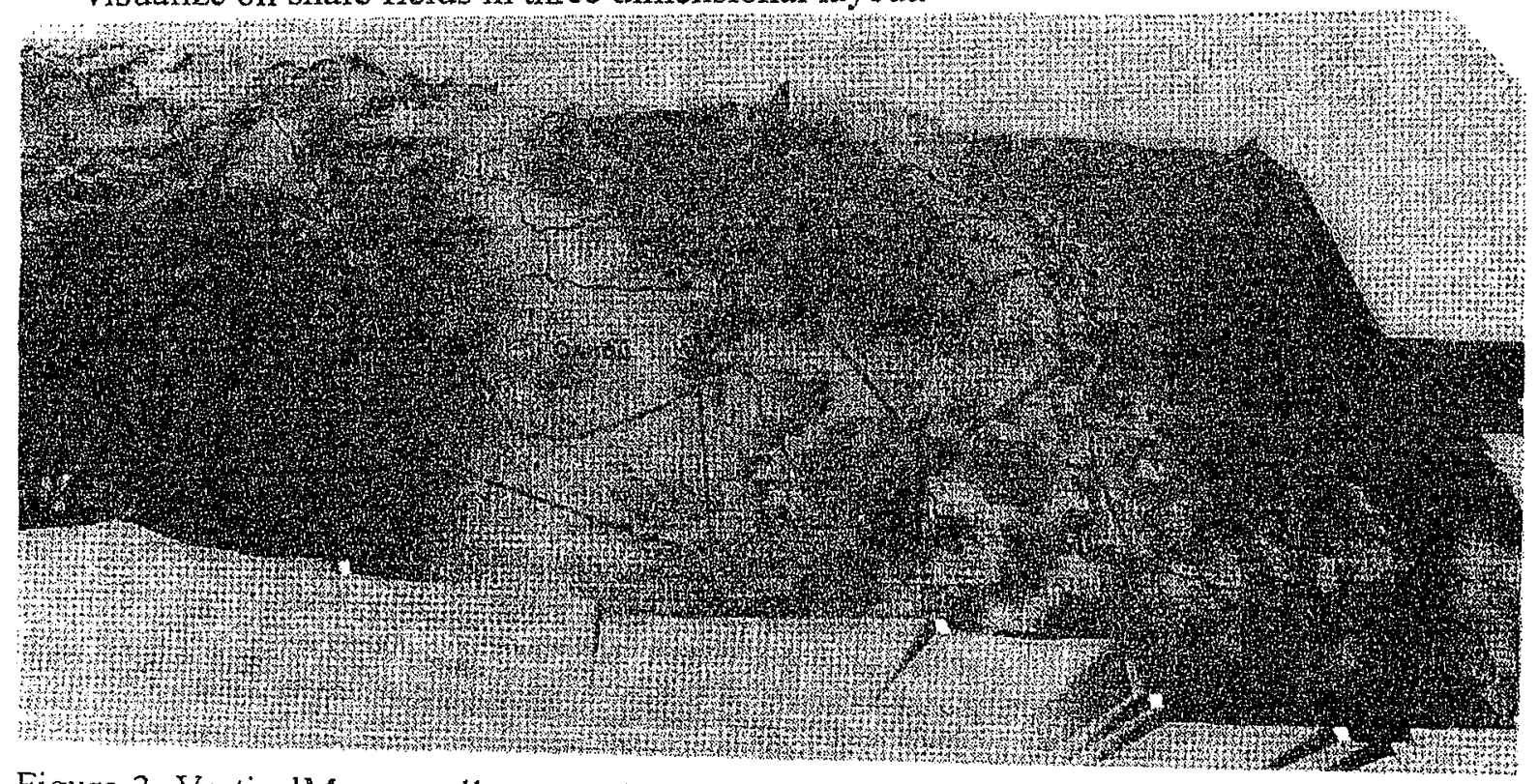

Figure 3. VerticalMapper allows to visualize surface elevation, showing oil shale mining and research fields of Estonian deposit, the black hills are ash deposits from oil shale burning (so
called ash hills)

\section{In Estonia, oil shale Oil shale mining in Estonia}

Open cast mining technology was unen in surface mines close to the outcrop until 1922. already in the depth of ten meters because the beginning. Underground mining started were applied both for drifting and stopine of the stable roof. Drill and blast methods were applied both for drifting and stoping. First stripping shovels and locomotives 
appeared in thirties. At the same time electric drilling began. Transition to the mechanized mining began in fifties. Until this, all mines used strait works technlogy, which meant handwork. After that, longwall mining, which was widely used by Russian coal mining, was applied. For oil shale mining, double unit face method was used. Mines applied cutters, conveyors, electric locomotives and force ventilators. In all of the mines electrification was started.

Estonian oil shale enterprises have used both surface and underground mining methods (See Table 1). In Estonia, four underground mining technologies have been in use; short wall stoping by handwork from 1920 and 1955, double face longwall mining from 1945 to 1965 , room and pillar mining since 1960 and longwall selective since 70 .

Table 1

Percentage of mined oil shale in last years classified by mining technology

\begin{tabular}{|l|l|l|l|l|}
\hline \multicolumn{1}{|c|}{ Mining and winning } & \multicolumn{1}{|c|}{ Separation } & $\begin{array}{c}\text { Estonian } \\
\text { deposit }\end{array}$ & $\begin{array}{c}\text { Leningrad } \\
\text { deposit }\end{array}$ & $\begin{array}{c}\text { Kashpirovka } \\
\text { deposit }\end{array}$ \\
\hline Open cast mining & 47 & 0 & 0 \\
\hline total-bed winning & Heavy medium separation & 15 & 0 & 0 \\
\hline Selective winning & Dry screening & 32 & 0 & 0 \\
\hline Underground mining & Heavy medium separation, & 37 & 0 & 100 \\
\hline room and pillar mining, & Jigging & & 100 \\
\hline $\begin{array}{l}\text { short faces } \\
\text { long faces }\end{array}$ & $\begin{array}{l}\text { Heavy media concentrating, } \\
\text { dry concentration }\end{array}$ & 0 & 100 & 0 \\
\hline $\begin{array}{l}\text { long wall selective } \\
\text { winning }\end{array}$ & Dry screening & 11 & 0 & 100 \\
\hline $\begin{array}{l}\text { short wall stoping of } \\
\text { pillars }\end{array}$ & Dry screening & 5 & 0 & 0 \\
\hline Total, per cents & & 100 & 100 & 100 \\
\hline
\end{tabular}

\section{Mapping underground mining situations}

While surface digital mapping has developed already several years in Estonia underground mapping has started just in the beginning of 1998. Data is taken from underground mine maps in scale of 1:5000 and 1:10 000. The knowledge received from digital mapping of underground mines- both closed and operating are used in variety of interests' fields. The main of them is locating areas with potential ground subsistence in today's urban situation. Other interests are prediction of ground water regime in closed mines, land usage planning, analyze of re-mining oil shale in areas with left resources. The study is part of the project "Post technological processes in mined areas" financed by Estonian Science Foundation.

Figure 6 shows applications of used technologies in Estonian and Russian oil shale industries. The main part of oil shale mined with room and pillar system and with open cast technology. 


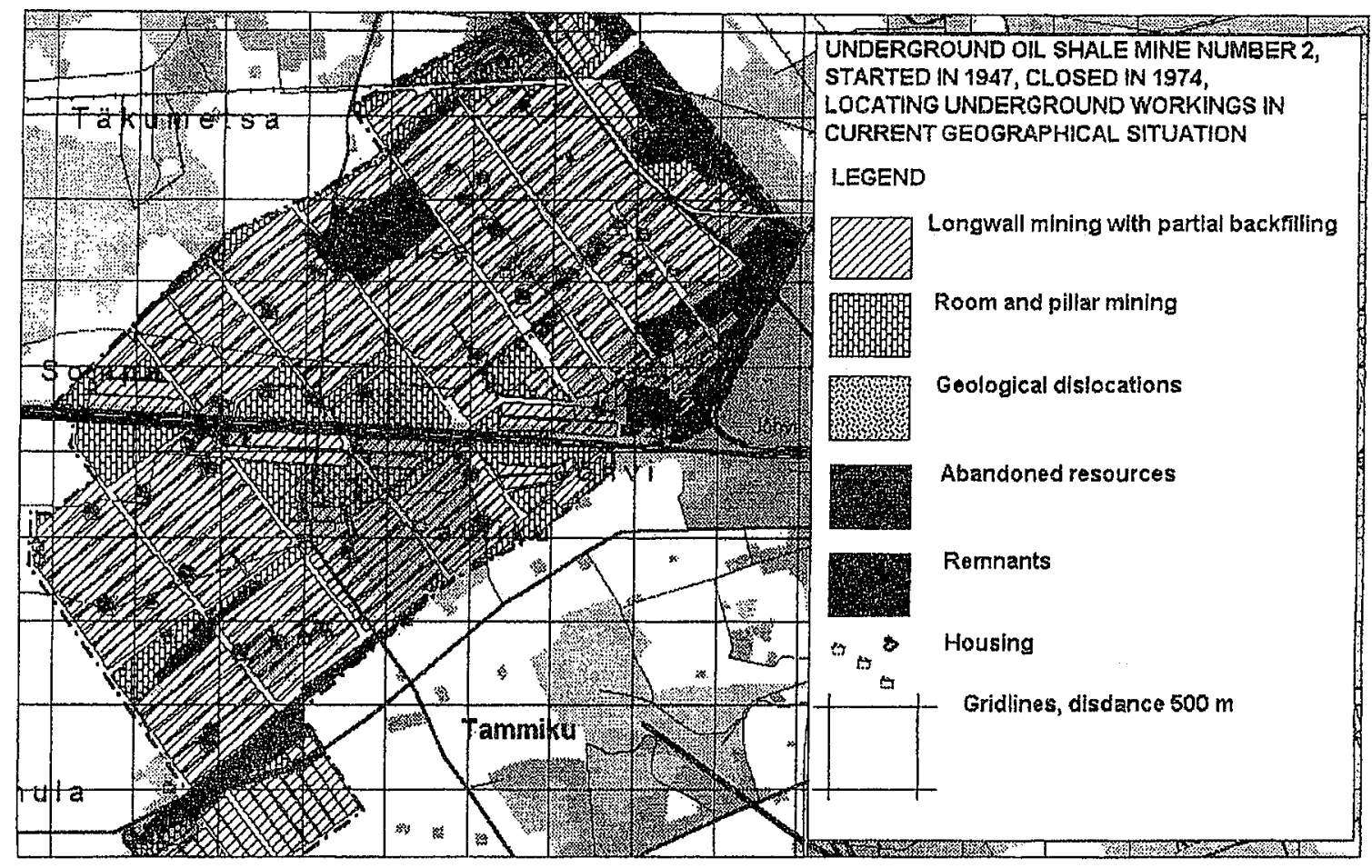

Figure 5 Map of underground workings in closed mine show potential areas of ground subsidence in current geographical situation

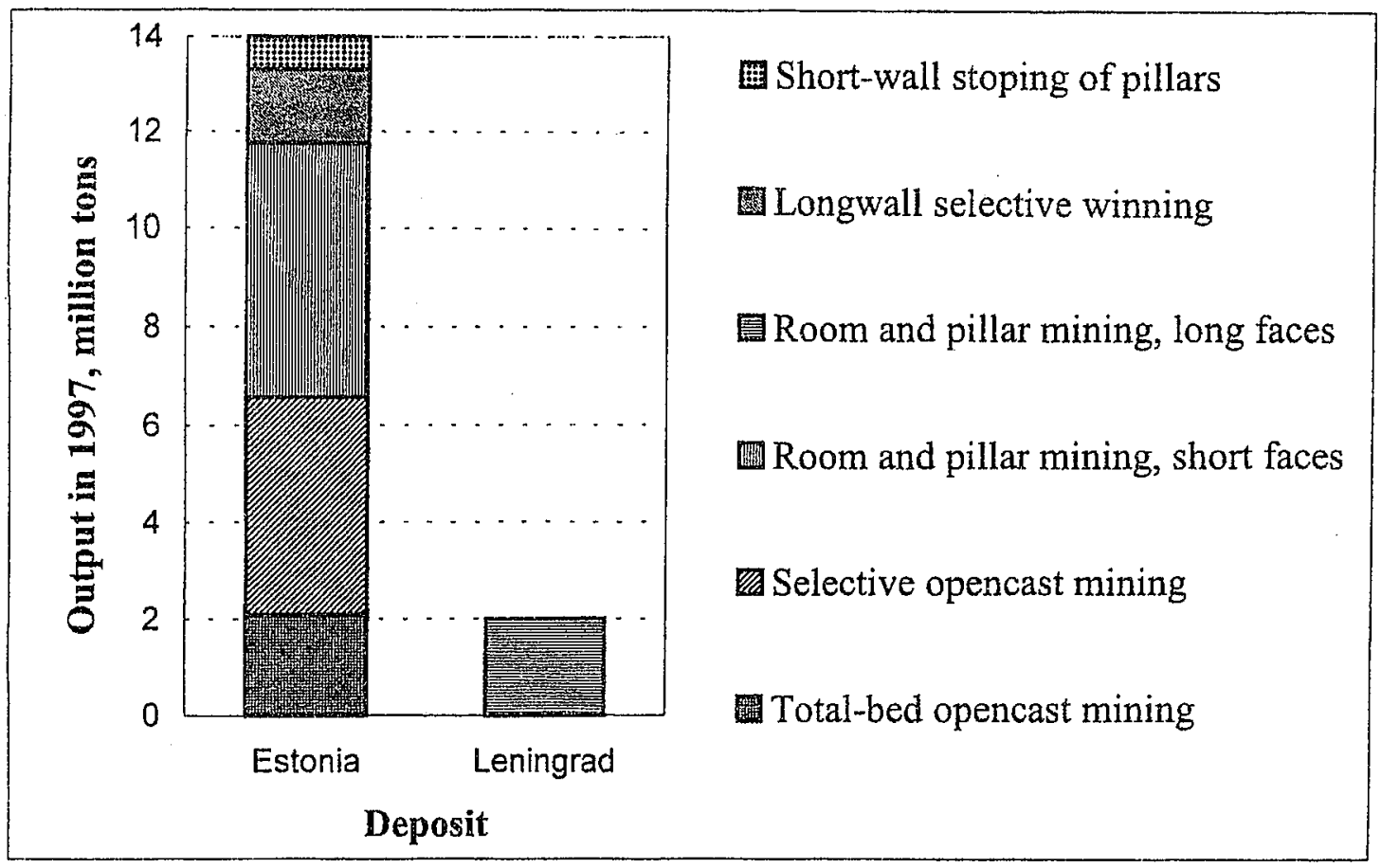

Figure 6. Distribution of mined oil shale quantity in 1997 by technologies in Baltic area 


\section{Underground mining}

In spite of low depth of oil shale bedding the underground mining have spread instead of surface mining. The main underground mining method is room and pillar mining (See Figure 6). The field of oil shale mine is divided into panels by the panel drifts. The panels are from 600 to $800 \mathrm{~m}$ wide and a number of kilometers long. The panel is divided into $350 \mathrm{~m}$ wide mining blocks. The main operations carried out in rooms include bottom cutting, drilling of blast holes, blasting, loading of blasted rock on the chain conveyer and supporting by bolts. Almost all equipment is made in Russia and Ukraine. They are shearers, drill jumbos, arm loaders, bulldozers and belt conveyers. The height of the rooms is correspondent to the thickness of the commercial oil shale bed. the width of the working is varying from 6 to $10 \mathrm{~m}$.

The main losses are in the pillars which area is 30 to $40 \mathrm{~m}^{2}$, depended from the depth of oil shale bed. Losses vary from 23 to 26 percent in average 25 percent. Conventional method of mining has been best by square form pillars. The mining technique in use, which are manufactured for coal mining has low productivity for oil shale mines. The other hand they are uncertain in work and too many machines are reqiured in the chambers.

In three mines the longwall mining method by shearer loaders with hydraulic roof support system is used. Underground mines cause the sinking of surface after mining activities, which leads to formation of wetland where agricultural area become unusable and forests dies.

\section{REFERENCES}

Baltic 21 Series No 1/98 (1998). An Agenda 21 for the Baltic Sea Region, Baltic 21 Adopted at the 7th Ministerial Session of the Council of the Baltic Sea States, Nyborg. [This is official development plan for the Baltic region]

Raukas A., Teedumäe A. (Edit.). (1997). Geology and mineral resources of Estonia, Institute of Geology, Estonian Academy Publishers. [This book provides latest information about Estonian geology and mineral resources]

Reinsaly E. (Edit.). (1998). Oil Shale, Vol. 15, No.2 Special, Departament of Mining, Tallinn Technical University, Tallinn. [This special issue of the magazine presents information about oil shale exploration and mining in Estonia]

Ingo Valma. An evaluation of technological overburden thickness limit of oil shale open casts by using draglines, Oil Shale, vol.15, No.2 Special, 1998, $134 \ldots 146$

Ingo Valgma. Using MapInfo Professional and Vertical Mapper for mapping Estonian oil shale deposit and analyzing technological limit of overburden thickness., Proceedings of International Conference on GIS for Earth Science Applications, Institute for Geology, Geotechnics and Geopysics, Slovenia, Ljubljana 17 ... 21 May $1998,187 \ldots 194$. 